\title{
On the relationship between attitudes and environmental behaviors of key Great Barrier Reef user groups
}

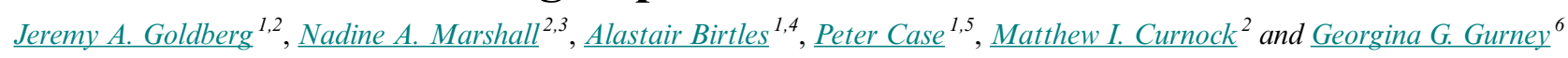

\begin{abstract}
Urgent action is required to address threats to ecosystems around the world. Coral reef ecosystems, like the Great Barrier Reef (GBR), are particularly vulnerable to human impacts such as coastal development, resource extraction, and climate change. Resource managers and policymakers along the GBR have consequently initiated a variety of programs to engage local stakeholders and promote conservation activities to protect the environment. However, little is known about how and why stakeholders feel connected to the GBR nor how this connection affects the proenvironmental behaviors they undertake. We present the results of 5891 surveys and show that the attitudes that residents, tourists, and tourism operators have about the GBR are closely tied to the behaviors and activities they take to protect the environment. Our findings suggest that the responsibility, pride, identity, and optimism that people associate with the GBR are significantly correlated to several proenvironmental behaviors, including recycling, participation in conservation groups, and certain climate change mitigation activities. Respondents who feel the strongest connection to the GBR take the most action to protect the environment. Tourism operators who strongly identify with the GBR take more action to protect the environment than those who do not. Encouraging individual identification with the GBR via targeted messages and engagement campaigns may assist not only in GBR conservation, but a wider sustainability movement as well. A better understanding of the individual attitudes and beliefs held by local stakeholders is a key first step toward effective communication to influence conservation activities.
\end{abstract}

Key Words: attitudes; behavior change; identity; optimism; pride; resource management; responsibility; tourism; World Heritage

\section{INTRODUCTION}

Ecosystems around the world are degrading due to human impacts such as unsustainable agricultural practices and environmental degradation (Perry et al. 2010, Vörösmarty et al. 2010). For example, global marine fisheries catches are in decline (Pauly and Zeller 2016), supplies of freshwater for agriculture are shrinking due to climate change (Grayson 2013), and an expansion of road networks is drastically intensifying habitat loss and resource extraction (Laurance et al. 2014).

Tropical habitats such as coral reefs are complex social-ecological systems (SES) that are particularly vulnerable to human impacts (Anthony et al. 2011, Frieler et al. 2012). Despite widespread recognition of the human role in the degradation and protection of coral reefs, most research neglects the human dimension and focuses solely on ecological issues (Kittinger et al. 2012). However, changes to the ecology of these systems are projected to have widespread and negative influences on reliant communities, individuals, and industries (Great Barrier Marine Park Authority 2014). Substantial impacts have already been documented on the Great Barrier Reef (GBR) as 50\% of the live coral cover on GBR has been lost over the last 30 years (Lewis et al. 2009, De'ath et al. 2012). Anthropogenic threats such as climate change and poor water quality, as well as cyclones and outbreaks of coral-eating starfish are considered to pose the greatest challenges for the future management of the GBR (Johnson and Marshall 2007, Mccook et al. 2010). Urgent action is required to sustain the integrity and productivity of the GBR (Hughes et al. 2010), particularly with the recent severe mass coral bleaching events in 2016 and 2017 (Hughes et al. 2017).
The creation of innovative conservation partnerships is particularly important to halt the ongoing degradation of natural resources (Biggs et al. 2012). Resource managers have consequently initiated a variety of collaborative programs and projects that encourage the protection of the GBR (Great Barrier Marine Park Authority 2007, 2012, Evans 2011). These programs operate at various scales in space and time, including large-scale initiatives such as the GBR rezoning in 2004 to protect $33 \%$ of the marine park from fishing as a no-take area (Fernandes et al. 2005), regional activities like the Reef Guardian campaign to promote community stewardship of natural resources (Evans 2011), and local actions such as the establishment of noanchoring areas around Keppel Bay in the Southern GBR (Beeden et al. 2014a). Projects like these devote considerable resources toward establishing strategic collaborations and knowledge sharing among community members, primary industries, and governments to take action to protect the GBR (Day and Dobbs 2013). Enhanced community understanding, shared learning, and public awareness are key components of successful adaptive management and help maintain the resilience of linked social-ecological systems (Olsson et al. 2004). Further, understanding how people relate to the environment is a key step toward designing resource management programs that encourage proenvironmental behaviors (Vaske and Kobrin 2001), including those that maintain or enhance valued attributes of that setting (Stedman 2002). One way to understand the connection that people have for a place is to clarify the meanings they associate with that setting (Wynveen et al. 2010).

${ }^{1}$ College of Business, Law and Governance, James Cook University, Townsville, Australia, ${ }^{2}$ CSIRO Land and Water, Townsville, Australia, ${ }^{3}$ College of Marine and Environmental Sciences, James Cook University, Townsville, Australia, ${ }^{4}$ College of Science and Engineering, James Cook University, ${ }^{5}$ Bristol Business School, University of West England, ${ }^{6}$ Australian Research Council Centre of Excellence for Coral Reef Studies, James Cook University 
Fig. 1. Relationship of respondents' proenvironmental behavior with Great Barrier Reef (GBR) attitudes, climate change belief, behavioral barriers, and demographic characteristics covariates. Coefficient estimates (dots) and 95\% confidence intervals (lines) for each covariate are shown for models of residents (A), tourists (B), and tourism operators $(\mathrm{C})$. Intersection of confidence intervals with the zero line indicates a lack of relationship between the relevant covariate and environmental behavior score. The reference category for gender is female. Note that following covariates were reverse-coded: affected by decline, responsibility of individual, time barrier, and cost barrier.

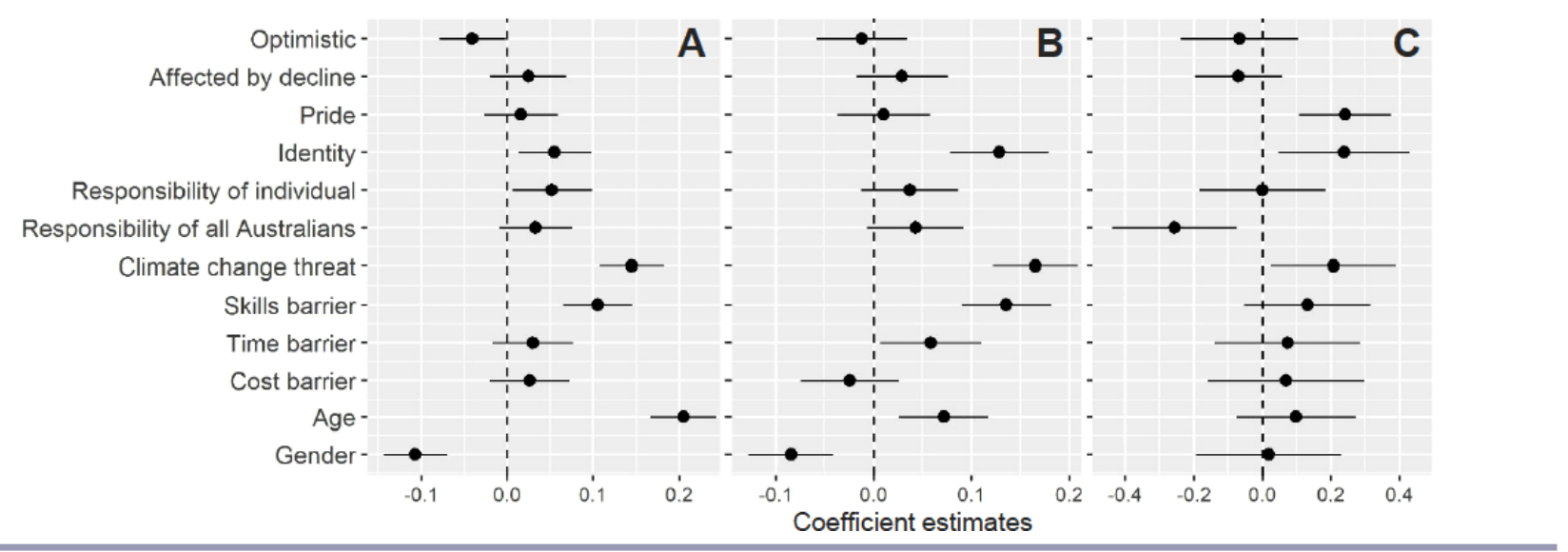

\section{Key influences on proenvironmental behavior}

The ways that people associate with nature can influence their opinions about resource protection and the behaviors they take in response to environmental threats (Devine-Wright and Clayton 2010). We discuss four key factors that are likely to affect the way that people connect to the GBR, including the pride, identity, personal affection, and levels of optimism they feel for the GBR (Fig. 1).

Pride in local resources may affect support for management decisions, including environmental activities such as the creation of marine protected areas (Ballantine 1995) and the advancement of community engagement programs that promote conservation of natural resources (Jenks et al. 2010).

Identity derived from a natural resource or place has been shown to influence the actions people take to cope with change in their circumstances resulting from altered environmental conditions (Marshall et al. 2012). Understanding the role of identity in facilitating behaviors that affect the natural world also has serious practical implications for the development of protective environmental policies and behaviors (Clayton and Opotow 2003).

The extent to which a person might be personally affected by the loss of nature may be attributed to the responsibility they feel to protect it (Adger et al. 2011). An emphasis on individual responsibility may promote deeper thinking about environmental threats (Rickard et al. 2014), higher levels of public participation in management decision making, and greater benefits for marine environments (Mckinley and Fletcher 2010).

Perceptions of optimism about the future affects the level of risk seeking or risk aversion that an individual feels (Hochschild et al. 2012), affecting the actions they take in response to those risks.

Positively biased assessments of local environmental conditions may create considerable challenges for behavior change campaigns (Macdonald et al. 2015), making it difficult to encourage people to take action or demand change if they do not recognize existing threats to local natural resources (Novacek 2008). For example, those who believe in the risk of climate change are more likely to take action to address it (Whitmarsh 2008). Further, if we do not examine how people perceive climate change, we will be unable to develop effective responses as a society (Clayton et al. 2015).

The initiation of proenvironmental behaviors can also be affected by perceived barriers to action, e.g., a lack of financial resources. Changing behaviors toward environmental conservation requires that people overcome perceived obstacles, including internal perceptions related to self-efficacy (van Riper et al. 2013), defined as "a person's estimate of his or her capacity to orchestrate performance on a specific task" (Gist and Mitchell 1992:183). For example, a resident who wants to recycle their waste may not do so if the conditions are perceived to be impractical (i.e., it is too expensive to recycle), improbable (e.g., they are too busy with other household tasks to devote time to recycling), or irrelevant to their worldview (e.g., they do not know what recycling is or why it is important; adapted from van Riper et al. 2013). In other words, the available time, knowledge, and skill related to a behavior may influence an individual's decision to act. This is important because the level of perceived ability required to carry out a behavior facilitates the transition from intentions to action (Armitage and Conner 2001) and is a strong predictor of the behavior itself (Moser and Dilling 2004). Thus, if individuals believe that they can undertake proenvironmental behaviors and they also feel they have the required skills and abilities, they are more likely to do them.

Another potentially important factor that can affect the success of strategies aiming to influence proenvironmental behaviors includes demographic traits such as gender and age. Although a majority of Australians agree that the community has a role to 
play in the protection of the GBR, beliefs can vary considerably depending on variables such as gender (Young and Mar 2010). Women express greater concern for the environment than men (Sundström and Mccright 2013) and gender has been shown to be a reliable predictor of environmental attitudes, intentions, and behaviors (Arnocky and Stroink 2010, Mobley and Kilbourne 2013). Previous research has also shown correlations between age and environmental concern and action (Buttel 1979, Honnold 1984), specifically that younger people express more concern for the environment than older individuals (Fransson and Gärling 1999). However, these correlations have not been confirmed within the GBR region. Thus, resource managers remain uncertain how best to utilize demographics between stakeholder groups to develop and refine communication approaches such as strategic message frames. Understanding the relationship between demographic variables and environmental attitudes may support a variety of conservation activities such as activism, empowering a collective effort among all individuals to improve the health and future of the environment (Zelezny et al. 2000).

\begin{abstract}
Aim and research questions
The aim of this study is to explore the attitudes held by local stakeholders about an iconic coral reef ecosystem, the GBR, and to describe how and why these attitudes relate to the proenvironmental behaviors they undertake. Previous research has demonstrated close and meaningful connections between individual attitudes and behaviors (Ajzen and Fishbein 2005, Devine-Wright and Howes 2010, Halpenny 2010). However, because of external influences such as social norms and institutional barriers, there is also evidence to suggest that attitudes may not necessarily be the main drivers of individual behavior (Griskevicius et al. 2008, Moser and Ekstrom 2010). Along the GBR, there has been little work done to clarify why stakeholders undertake specific proenvironmental behaviors. Stakeholder groups vary in the ways they use, connect, and care for the GBR (Curnock et al. 2014a, Tobin et al. 2014a, b). Consequently, clarification of the links between attitudes and proenvironmental behaviors would be a beneficial first step for practitioners seeking to promote conservation activities in the GBR region.
\end{abstract}

The examination of the social-ecological system of the GBR is thus a useful case study to explore new ways of connecting with stakeholders about the sustainable use and long-term preservation of the GBR. This is especially important because there is considerable interest from conservation groups and government agencies to ensure that management is as efficient and effective as possible (McCook et al. 2010, Dobbs et al. 2011, Beeden et al. 2014a, $b$ ). Of particular interest are the obligations of the Australian Government to protect the outstanding universal value of the GBR as part of the World Heritage Convention (Lucas et al. 1997) as well as the promotion of proenvironmental behaviors that address climate change impacts (Wynveen and Sutton 2015). Research that clarifies the ways that stakeholders feel about the conservation of the GBR is likely to be well received and operationalized in a resource management context.

We explore four research questions related to the proenvironmental behaviors undertaken by individuals within three key GBR user groups (residents, tourists, and tourism operators). These user groups represent the vast majority of people who use the GBR. Other stakeholders such as farmers and fishers are undoubtedly important but are beyond the scope of this study. The four research questions we explored are:

1. Are attitudes about the GBR correlated with taking action to protect the environment? That is, do individuals that undertake certain proenvironmental behaviors have different levels of connection to the GBR than individuals who choose not to take action?

2. What barriers prevent GBR stakeholders from undertaking proenvironmental behaviors?

3. Do people who believe more strongly in the severity of climate change take more action to protect the environment?

4. Do the latter relationships differ among the three key GBR stakeholder groups?

\section{METHODS}

\section{Study area}

The GBR is the world's largest coral reef ecosystem, spanning more than $344,000 \mathrm{~km}^{2}$ (Great Barrier Marine Park Authority 2009), including more than 3000 individual reefs and stretching for more than $2000 \mathrm{~km}$ along the Queensland coast in northeastern Australia. It also provides huge employment and economic contributions to Australia (Bohensky et al. 2014, Tobin et al. 2014a), particularly the tourism industry, which contributes about 64,000 full-time jobs and more than A\$5.2 billion to the Australian economy each year (Deloitte Access Economics 2013). The GBR also plays a role in the lives of people throughout Australia, e.g., as a source of inspiration and pride for most Australians (Goldberg et al. 2016) and attracting thousands of domestic visitors each year (Biggs 2011). To address the research questions, we conducted face-to-face surveys of two key user groups, residents and tourists in the GBR region, as well as telephone surveys with marine tourism operators. These data collection efforts had three parts: survey design, survey administration, and data analysis.

\section{Survey design}

A survey template was developed, which included all of the data needs in a generic survey form that could be adapted and customized for each of the three targeted user groups: coastal residents living along the GBR, tourists visiting the GBR region, and tourism operators working within the GBR Marine Park. Survey questions were presented as statements and based upon previous regional studies where possible (Moscardo 2008, Marshall et al. 2009, Marshall 2010, Young and Mar 2010, van Riper et al. 2013).

We examined how proenvironmental behavior was related to six covariates capturing attitudes toward the GBR and its management, and three covariates capturing potential perceived barriers to performing proenvironmental behavior (Table 1). We also examined how proenvironmental behavior was related to a single covariate capturing perceived severity of climate change. This covariate was operationalized by five statements that related to five levels of severity of climate change; respondents were asked to identify which of five statements best described their belief about climate change and were given a score of one (least severe) 
Table 1. Description of our covariates. The following covariates were reverse-coded: affected by decline, responsibility of individual, time barrier, and cost barrier.

\begin{tabular}{|c|c|c|}
\hline & Covariate name & Likert-scale statement \\
\hline \multicolumn{3}{|c|}{ Attitudinal statements about the Great Barrier Reef (GBR) } \\
\hline \multirow[t]{4}{*}{ Concern and connection } & Optimistic & I feel optimistic about the future of the GBR \\
\hline & Affected by decline & I would NOT be personally affected if the health of the GBR declined \\
\hline & Pride & I feel proud that the GBR is a World Heritage Area \\
\hline & Identity & The GBR is part of my identity \\
\hline \multirow[t]{2}{*}{ Responsibility } & Responsibility of individual & It is NOT my responsibility to protect the GBR \\
\hline & Responsibility of all Australians & It is the responsibility of all Australians to protect the GBR \\
\hline \multicolumn{3}{|c|}{ Perceptions of reducing impact on the GBR } \\
\hline \multirow[t]{3}{*}{ Perceived self-efficacy } & Skills barrier & $\begin{array}{l}\text { I have the necessary knowledge and skills to reduce any impact I might } \\
\text { have on the GBR }\end{array}$ \\
\hline & Time barrier & $\begin{array}{l}\text { I do NOT have the time and opportunity to reduce any impact that I } \\
\text { might have on the GBR }\end{array}$ \\
\hline & Cost barrier & $\begin{array}{l}\text { It is too expensive for me to reduce any impact I might have on the } \\
\text { GBR }\end{array}$ \\
\hline
\end{tabular}

to five (most severe). These statements were taken from previous regional studies (Young and Temperton 2008, Young and Mar 2010).

Respondents rated their agreement or disagreement with the 9 statements using a 10-point response scale, ranging from 1 (very strongly disagree) to 10 (very strongly agree). A 10-point scale was considered suitably sensitive to detect subtle fluctuations (Nunnally 1978, Horton and Hunt 1984) and the lack of a midpoint prevented the assumption of the following responses: undecided, unknown, not sure, neutral, cannot be bothered (Marshall 2006). Further details about the survey methods, design, and administration can be found in (Bohensky et al. 2014, Curnock et al. 2014a, Tobin et al. 2014b). The final questionnaire versions can be accessed by contacting the primary author.

Respondents were asked to self-identify their gender and were presented with three choices: male, female, and other. The other category offered an open-ended space for respondents to clarify their gender.

Finally, respondents were asked how frequently they participate in various proenvironmental behaviors (Table 2). These behaviors were selected by reviewing resource management policies and programs most relevant to climate change, tourism, and the GBR (Great Barrier Marine Park Authority 2007, 2012 Young and Temperton 2008, Young and Mar 2010). They reflect a broad suite of possible responses, including consumer purchases, community activism, climate change mitigation, and participation in conservation activities. They are also tailored to each of the three user groups. In addition to these behaviors, residents and tourists were asked to rate how often they did them, i.e., never, sometimes, often, or always. For the tourism operators, many of the behaviors related to the manner in which they ran their business and thus required an evaluation of presence or absence rather than frequency, i.e., are they doing them versus how often they are doing them.

\section{Survey administration}

An initial version of the questionnaire was pilot tested within each user group to ensure survey questions were clear and unambiguous. Following revision, face-to-face surveys of coastal residents $(n=3,181)$ and tourists $(n=2,621)$ were conducted from June to September, 2013. Residents were defined as individuals living within the GBR catchment (east of the Great Dividing Range, from Bundaberg to Cape York), whereas for the purposes of this survey, tourists were broadly defined as people who lived outside of that area, whether elsewhere in Australia or overseas.

A combination of convenience sampling and quota sampling (Bryman 2012) was used to produce a population survey, which was representative across broad demographic categories such as age, gender, occupation, and ethnicity. Further, we sought to ensure that our limited available resources enabled stratified sampling in all of the main regions along the GBR coastline. For tourists, convenience sampling was used because of the difficulty in defining the population, a requirement for random sampling. To reduce the likelihood of sampling bias, surveys were conducted at strategic coastal locations across the GBR region (from Bundaberg to Cooktown) and included popular public locations such as airports, caravan parks, shopping centres, community markets, and marinas. We also surveyed at different times of the day. This mixed methods approach to survey administration resulted in a high response rate $(\sim 53 \%)$ however our sampling included a bias toward English-speaking people.

An important limitation in our study is that we considered selfreported proenvironmental behaviors rather than observed behaviors. Although research related to human behavior regularly relies on self-reporting with respect to surveys (Steg and Vlek 2009), discrepancies between self-reported and observed behavior do occur (Armitage and Conner 2001). Because respondents were self-reporting environmental behaviors, social desirability bias is a concern, i.e., the respondent seeking social approval and acceptance via their responses. In this scenario, people tend to portray themselves in a more favorable light, presenting their answers more for social acceptability rather than an accurate reflection of their true feelings (Podsakoff et al. 2003). However, self-reports have been shown to be acceptable indicators of actual behavior (Warriner et al. 1984, Fuj et al. 1985). Although we cannot assess potential discrepancies in our study, an important next step of this research would be to examine real-world behaviors. 
Table 2. The proenvironmental behaviors included in each survey. GBRMPA = Great Barrier Reef Marine Park Authority.

\begin{tabular}{|c|c|c|}
\hline Resident behaviors & Tourist behaviors & Tourism operator behaviors \\
\hline $\begin{array}{l}\text { - Recycle } \\
\text { - Bring own bags to the supermarket } \\
\text { - Engage in environmental community programs }\end{array}$ & $\begin{array}{l}\text { - Recycle } \\
\text { - Prioritize environmentally friendly products } \\
\text { when shopping } \\
\text { - Use carbon offsets to counter emissions } \\
\text { - Choose accommodation based on "green" } \\
\text { credentials } \\
\text { - Choose a tour operator based on "green" } \\
\text { credentials }\end{array}$ & $\begin{array}{l}\text { - Separate waste created by tourists for recycling } \\
\text { - Separate waste created by tourists for recycling } \\
\text { - Use an emissions calculator to plan business } \\
\text { operations } \\
\text { - Use carbon offsets to counter emissions } \\
\text { - Use green energy, such as solar panels, for any } \\
\text { part of the business } \\
\text { - Use alternative fuels such as biodiesel and } \\
\text { ethanol } \\
\text { - Participate in industry best practices, via a code } \\
\text { of practice or MOU } \\
\text { - Participate in GBRMPA's Reef Guardian } \\
\text { Program } \\
\text { - Participate in GBRMPA's Eye on The Reef } \\
\text { Program } \\
\text { - Provide interpretation for tourists that } \\
\text { promotes conservation or sustainable use of the } \\
\text { Great Barrier Reef } \\
\text { - Have fuel- efficient engines }\end{array}$ \\
\hline
\end{tabular}

Tourism operators were surveyed via telephone following the creation of a database that identified all GBR tourism businesses currently in operation (Curnock et al. 2014b). This database was created following a comprehensive web search and snowball sampling once surveys were underway. A total of 213 tourism businesses were identified and asked to participate in this study. Of these 34 declined, 57 were unresponsive, and 122 agreed to be interviewed. Surveys were completed for 119 tourism operators.

\section{Description of the survey samples}

The data presented were collected as part of baseline surveys conducted by the Social and Economic Long-Term Monitoring Program in 2013. This program provided a large-scale overview of the relationship between people and the Great Barrier Reef, particularly the status, trends, and condition of key user groups (Marshall et al.2016). For more information, detailed results from those surveys can be downloaded from http://seltmp.eatlas.org. $\mathrm{au} / \mathrm{seltmp}$ including information related to resident and tourist well-being, values, stewardship, resilience, resource use, and dependency.

We provide a brief description of the three user groups included in this study:

- Half of the coastal resident respondents were female (50\%) and the average age was 44 . The most commonly cited occupations were government, health, and education $(17 \%$ of respondents) followed by mining $(11 \%)$ and trade $(8 \%)$. Respondents' annual incomes were dispersed, with about $65 \%$ earning less than US\$100,000 and 12\% earning less than US\$20,000 per annum. Approximately 25\% of residents derived some of their household income from the GBR. For greater detail about the 3181 coastal residents surveyed, please see (Tobin et al. 2014b).

- Among the tourist respondents included in this study, $44 \%$ were visiting the GBR region on holiday, $14 \%$ for work or a meeting, and $12 \%$ were visiting friends and family. Most of the tourists were Australian (54\%) or European (United
Kingdom 11\%; Germany $8 \%$; France $7 \%$ ). The average age of the tourists was $40,50 \%$ were female, and they had a median stay of 9 days in the region. For greater detail about the 2621 tourists surveyed, please see (Curnock et al. 2014a)

- Of the 119 tourism operators surveyed, 46 were involved in reef tours, e.g., dive and snorkel trips, 28 were charter fishers, and 14 were involved with island resorts or accommodation. Respondents had 14 years of experience in the GBR tourism industry on average. Their businesses employed a mean of 22 full-time staff, had been in business for 18 years, and had spent 232 days operating in the GBR region over the previous year. Most of the respondents were male (79\%), the average age was $47,82 \%$ were married, $76 \%$ had some form of university or higher education, and approximately $88 \%$ of their household income came from tourism along the GBR.

\section{Data analyses}

A composite environmental behavior score was calculated for every respondent in each user group depending upon how often (tourists and residents) or whether or not (tourism operators) they exhibited various proenvironmental behaviors (Table 2). Tourism operators who had more proenvironmental behaviors (and for residents and tourists, those who had them more often) received higher scores than those who did not (Table 3 ).

To assess how environmental behavior (our dependent variable) was related to GBR attitudes, climate change belief, behavioral barriers, and demographic characteristics (our covariates) we used three general linear models, one for each of the user groups. Separate models were used for each user group given the different behavior scoring systems and therefore discrepancies between possible maximum and minimum scores between user groups. All covariates (except gender) were standardized by subtracting the mean and dividing by twice the standard deviation (Gelman 2008), allowing us to compare across covariates based on different measures. We also standardized the environmental behavior score 
Table 3. The scoring system used to quantify a composite environmental behavior score for each respondent.

\begin{tabular}{|c|c|c|c|c|}
\hline User group & Number of behaviors & Scoring system & Minimum score & Maximum score \\
\hline Tourism operators & 10 & $\begin{array}{l}\text { Yes }-1 \text { point } \\
\text { No }-0 \text { points }\end{array}$ & 0 & 10 \\
\hline $\begin{array}{l}\text { Tourists } \\
\text { Residents }\end{array}$ & $\begin{array}{l}5 \\
3\end{array}$ & $\begin{array}{l}\text { Never - } 1 \text { point } \\
\text { Sometimes }-2 \text { points } \\
\text { Often }-3 \text { points } \\
\text { Always }-4 \text { points }\end{array}$ & $\begin{array}{l}5 \\
3\end{array}$ & $\begin{array}{l}20 \\
12\end{array}$ \\
\hline
\end{tabular}

for each user group so that coefficient estimates were comparable among the three models. Covariates were first checked for collinearity by calculating Pearson correlation coefficients and variance inflation factors (VIF). We did not remove any covariates from the models because all covariates had a VIF $<3$ and all pairs of covariates had a correlation coefficient $<0.6$. Each model was examined for normality and homoscedasticity. The latter assumption was not met for the residents and tourists' models and therefore, robust standard errors were calculated and used to estimate coefficient confidence intervals for these models. Given that our intention was to assess the relative influence of various factors in influencing environmental behavior (rather than derive a predictive model), we retained all covariates in our models. All analyses were undertake using R 3.3.2 (R Core Team 2017).

\section{RESULTS}

Behavior scores were calculated for all individuals within the three main user groups. Most respondents received scores that were approximately in the middle of the scoring range. Less than $10 \%$ of respondents within each user group received the two highest or lowest possible scores, e.g., the highest possible scores for residents were 11 or 12 out of 12 , whereas the lowest possible scores were a 3 or 4 . Approximately $69 \%$ of residents scored 6, 7, 8 , or 9 out of a maximum of $12,72 \%$ of tourism operators had scores of $3,4,5$, or 6 out of 10 possible, and $53 \%$ of tourists scored a $9,10,11$, or 12 out of 20 .

The only attitudinal covariate significantly related to proenvironmental behavior across the three stakeholder groups was identity. Stakeholders who closely identified with the reef were more likely to participate in proenvironmental behavior (Fig. 1). Pride was also significantly related to proenvironmental behavior for tourism operators. Perceived individual responsibility to protect the GBR was significantly related only to residents' proenvironmental behavior. Perceived responsibility of all Australians to protect the GBR was significantly related only to tourism operators' behavior.

Respondent perceptions about the severity of climate change was significantly related with behavior scores across all three user groups (Fig. 1). That is, respondents who strongly believed that climate change was a severe threat requiring action were more likely to be undertaking proenvironmental behaviors than respondents who believed less strongly in climate change, i.e., those who required more evidence to be convinced of the problem and those who did not believe climate change was a threat.
The only covariate relating to perceived barriers to proenvironmental behavior that was significantly related to residents' behavior was the barrier related to possessing skills and knowledge; such that residents who perceived they had the skills and knowledge to protect the reef were more likely to be engaged in proenvironmental behavior (Fig. 1). For tourists, possessing knowledge and skills, as well as time, were significantly related to proenvironmental behavior scores. The behavior scores of tourism operators were not significantly related to any of the statements related to perceived barriers to action.

Age and gender were significantly related to the proenvironmental behavior scores received by tourists and residents (Fig. 1). Older people were doing more to protect the environment than younger individuals, and women were doing more than men. The behavior scores of tourism operators were not significantly related to the age or gender of respondents.

\section{DISCUSSION}

We found significant relationships between the way that people think about the GBR and the actions they take to protect the environment. Specifically, we showed that proenvironmental behaviors were related to the ways people perceived barriers to reducing their impact on the GBR, how connected they were to the GBR, how they perceived the severity of the climate change threat, and demographic characteristics such as age and gender. In other words, when people believe they are a part of the environment, not apart from the environment, they may be more likely to protect that environment and behave in ways that conserve it.

\section{Proenvironmental behaviors and attitudes about the Great Barrier Reef (GBR)}

A majority of respondents within each GBR user group were not undertaking proenvironmental behaviors to the maximum possible extent, i.e., they could be doing more proenvironmental activities more often. For example, just $7.5 \%$ of residents received the two highest behavior scores possible, with similar findings for tourism operators $(4.2 \%)$ and tourists $(1.2 \%)$. However, strong apathy and indifference were also rare, with just $5.8 \%$ of residents scoring in the two lowest scores, compared to $10.2 \%$ of tourism operators and $3.4 \%$ of tourists. Thus, people were taking action with respect to proenvironmental behaviors, yet many could do more. In addition to action, we also documented widespread interest with respect to numerous proenvironmental behaviors. Consequently, we believe the ongoing actions that stakeholders are currently taking to protect the environment represent a solid 
foundation upon which to build greater individual involvement in conservation activities. For example, Kollmuss and Agyeman (2002) showed that external factors such as behavioral incentives and feedback can influence why people display proenvironmental behaviors. If resource managers can identify effective ways to encourage ongoing behaviors of local stakeholders and motivate them to do more, they may inspire greater action among community members already working to protect and sustain their local environment.

The only attitudinal statement across all user groups that was significantly related to proenvironmental behaviors was identity derived from the GBR. That is, people who agreed that the GBR was part of their identity were more likely to be taking action to protect the environment, regardless of user group (Biggs et al. 2012). This is an original finding that deserves follow up, particularly as sense of identity has been shown to affect the way that individuals make decisions in response to climate change (Adger et al. 2011, Scannell and Gifford 2013). These findings also support previous research showing that personal connection to natural places can shape opinions about resource protection and influence behaviors taken in response to perceived environmental threats (Devine-Wright and Clayton 2010). Personal connection and identity with the environment can also influence how lower-income tourism operators cope with and respond to environmental change (Biggs et al. 2015). Thus, facilitating individual connections with nature and enabling people to connect with the environment may have practical implications for resource management and conservation outcomes (Halpenny 2010).

In addition to identity, proenvironmental behaviors of residents were significantly related to perceived individual responsibility to protect the GBR. That is, respondents who were more closely connected to the GBR were more likely to take proenvironmental action to ensure the conservation and preservation of the natural world around them. These findings support previous research showing that the way people connect with nature provides insights into how they treat the environment (Nisbet et al. 2009), including the ways they may choose to protect it (Schultz 2000). That is, people who value nature and feel concern for it will be more inclined to protect it (Howard 1997). The close connection that people have with an environmental icon like the GBR reinforces the important influence the environment has in the lives of people. Understanding how and why stakeholders are connected to the GBR can contribute significantly to its better protection.

Proenvironmental behaviors and belief in climate change Individual belief in climate change was significantly related to the proenvironmental behaviors undertaken by respondents across all three user groups. That is, respondents who acknowledged and appreciated the severity of climate change were more inclined to take action to protect the environment than respondents who believed that climate change was a less serious threat. Thus, it appears that our results support previous findings that threat acknowledgment is a key first step toward generating an effective response (Milliken 1987). If people do not understand or appreciate the potential impact of climate change on themselves and on the environment, it is difficult to convince them to take responsive action to address this threat (Grothmann and Patt 2005). Responsive actions may occur via a variety of behaviors including mitigation activities, community activism, and making choices as a consumer. However, it may also be that the relationship between climate change attitudes and proenvironmental behavior is not causal. It may be that people who are inclined to be less active with respect to their environmental behavior may also be less inclined to learn about environmental phenomena such as climate change. In this way, those with less knowledge about threats to the GBR such as climate change may also be less interested in the actions they can take to protect it. Regardless, effectively responding to climate change will take a widespread change in both attitude and behavior (Shove 2010), and threat perceptions related to climate change appear to be related to the actions that GBR stakeholders take to protect the environment.

\section{Proenvironmental behaviors and barriers to action}

Individual proenvironmental behaviors among residents and tourists were significantly related to several perceived barriers to action, including external constraints and internal beliefs related to a lack of knowledge, skills, and time. Residents and tourists who felt they lacked knowledge and/or skills were less likely to undertake proenvironmental behaviors such as recycling or the purchase of carbon offsets than respondents who believed they did not lack knowledge/skills. Tourists were also impeded by a lack of time, with those who felt they did not have the time to reduce their impact less likely to take action than those who felt they did have time. We did not clarify with tourists why they felt time was a limiting factor for action, just that it was. Future research that explores tourist perceptions of how much time is necessary to make a difference on the environment would be worthwhile. Lack of financial resources was not related to the behavior scores of any of the three stakeholder groups, suggesting that cost of action is not a significant barrier to the proenvironmental actions included in this study. These findings support previous research that showed those who perceived barriers to action were less likely to act (Gist and Mitchell 1992, O'Neill and Nicholson-Cole 2009). Individual self-efficacy has been shown to be a key component of the decision-making process that can impede or encourage certain behaviors depending upon individual perceptions (Gist and Mitchell 1992). Proenvironmental behaviors of tourism operators were not significantly associated with barriers related to a lack of time, money, or knowledge. Consequently, their lack of action may be due to other barriers, such as psychological constraints related to motivation (van der Linden 2015) or perceived self-efficacy (Gist and Mitchell 1992), as well as other constraints related to regulation or infrastructure (Biggs et al. 2012).

\section{Proenvironmental behaviors and demographics}

Older residents and women took significantly more action to help protect the GBR than younger individuals. These results conflict with previous research showing that young people, i.e., aged 18-24, are generally more supportive of environmental activism and sustainability than older age groups (Buttel 1979, Honnold 1984, Connell et al. 1999, Fransson and Garling 1999). However, the influence of age on proenvironmental behavior is complex. When young people are asked about the relative importance of issues, they tend to rank the environment as a fairly low priority (Partridge 2008). Additionally, and depending on the context, younger people may be significantly less likely to engage in proenvironmental behaviors than older individuals (DEC-NSW 2006). Our findings support this for reasons as yet unknown. 
We also learned that women took significantly more action to protect the environment than men. This finding supports previous research that showed that gender may be an influential indicator of environmental concern and behavior (Mobley and Kilbourne 2013, Sundström and Mccright 2013). Women may thus be a more receptive and actively engaged audience with which to discuss environmental activities or solicit support for management decisions.

Resource managers may also use this finding to inform the development of strategic messaging or selection of messengers used to convey information related to the sustainable use of the GBR. The choice of messengers is a critical element of successful engagement, and people are more inclined to accept and trust messages received from individuals with similar views, e.g., women with children may be more easily convinced by women in similar life situations (Malka et al. 2009). Indeed, a finer understanding of the messenger and the audience will help to ensure that the information conveyed and the dialogue between them meets the desired goals of the interaction (Moser 2010).

\section{Implications for management and engagement}

Clarifying and understanding the main differences between user groups is a first step in developing programs and projects that are able to influence individual proenvironmental behaviors of key stakeholders. The attitudes that people have about the GBR are related to proenvironmental behaviors and, consequently, resource managers have an opportunity to use this connection to encourage people to undertake proenvironment behavior. However, the initiation of behavior change is not simply a process whereby resource managers can communicate generally to a wide audience. Previous research has shown that engagement does not work that easily and segmentation of the audience may be appropriate (Maibach et al. 2011). Different types of individuals make up these different user groups. Some may be very enthusiastic about making a difference whereas others may be more apathetic. Clarifying these similarities and differences will be an important step to developing successful engagement and interpretation programs. We recommend that future research focus on five key areas:

1. The role of identity in influencing proenvironmental behaviors: Future research should seek to explain and clarify this connection, particularly the ways in which identity derived from the GBR is influenced and maintained. As identity was significantly related to proenvironmental behavior across all three user groups, this may be a useful way to frame broad conservation messages to a widespread and diverse audience. How messaging can be designed to resonate with and appeal to identity: understanding the impact of messages with an identity frame, i.e., in comparison to others that focus upon pride, responsibility, etc., is also a worthwhile endeavor because this would help clarify which messages are most resonant or impactful to influence stakeholder perceptions and behaviors. Future research that clarifies the messages and frames that enhance the individual connection to the GBR, specifically identity, would be beneficial for program managers and policy makers (Clayton and Opotow 2003).

2. How messaging can be designed to resonate with and appeal to identity: Understanding the impact of messages with an identity frame, i.e., in comparison to others that focus upon pride, responsibility, etc., is also a worthwhile endeavor because this would help clarify which messages are most resonant or impactful to influence stakeholder perceptions and behaviors. Future research that clarifies the messages and frames that enhance the individual connection to the GBR, specifically identity, would be beneficial for program managers and policy makers ( Clayton and Opotow 2003).

3. How threat perceptions affect decision making among GBR stakeholders: Further research is required to clarify the links between threat perceptions and the responsive actions taken by key stakeholders such as tourism operators. External forces such as government policies can influence responsive action among marine tourism operators, e.g., Biggs et al. (2012) showed government policies such as cumbersome regulations may have an impact on alternative fuel usage. However, there is little known about how individual beliefs affect actions taken to respond to climate change. Studies that elucidate the link between proenvironmental behaviors and climate change beliefs would be especially beneficial for resource managers seeking to inspire action among local stakeholders to address this threat. For instance, we have shown a relationship between climate change perceptions and proenvironmental behaviors, but we do not know if a causality exists between the two. We also do not fully understand how threat perceptions influence the actions people take to directly protect the GBR.

4. Identification of key barriers to specific proenvironmental behaviors: Research that identifies obstacles preventing stakeholders from taking action to protect the environment would be especially useful. We showed that general obstacles like a lack of time and knowledge are related to whether or not an individual takes action to protect the environment. If researchers can identify individual barriers that prevent specific proenvironmental behaviors from being undertaken by stakeholders, resource managers will be better placed to develop programs that can overcome these barriers. For example, follow-up surveys with tourism operators may help to clarify how and why they undertake certain proenvironmental behaviors such as the use of alternative fuels like biodiesel. In-depth analysis may identify barriers to action that are specific to that user group as well as that action. In addition to identifying obstacles, this research may also develop solutions, including the ways that resource managers may help tourism operators to do more to help protect the environment, with specific attention given to the solutions that tourism operators need and request. Similar work can also be done for additional user groups such as commercial fishers and farmers.

5. Expansion of this research to include other stakeholder groups: Farmers and commercial and recreational fishers and farmers are crucial components of the social-ecological system along the GBR. An improved understanding of their attitudes and proenvironmental behaviors would provide a clearer and more comprehensive approach to community engagement in the region. 


\section{CONCLUSIONS}

Coral reefs like the GBR are vulnerable to climate change and other anthropogenic impacts. These impacts are likely to cause severe disruptions in the lives of stakeholders who rely upon the GBR for recreational and economic opportunities. Consequently, resource managers seek to implement a variety of programs and policies that help minimize the degradation of the resource while maximizing the conservation response from key stakeholder groups. Understanding why and how the GBR affects the attitudes and actions of local stakeholders can help resource managers plan projects more effectively, including those that protect the environment, conserve natural resources, and address climate change. We found that strong connections to the GBR, particularly related to identity, were significantly related to a greater tendency to take actions that protect the environment. Encouraging individual identification with the GBR via targeted messages and engagement campaigns may assist not only in coral reef conservation, but a wider sustainability movement as well. A more holistic understanding of the connection that people have with the local environment may assist with the development of community engagement approaches that encourage people to take action to protect these very special places.

Responses to this article can be read online at: http://www.ecologyandsociety.org/issues/responses. $\mathrm{php} / 10048$

\section{Acknowledgments:}

Funding was provided by an International Postgraduate Research Scholarship from James Cook University to JG. Surveys were conducted with support from the NERP/CSIRO to NM. GGG recognizes support from the ARC Centre of Excellence for Coral Reef Studies.

\section{LITERATURE CITED}

Adger, W. N., J. Barnett, F. S. Chapin, III, and H. Ellemor. 2011. This must be the place: underrepresentation of identity and meaning in climate change decision-making. Global Environmental Politics 11(2):1-25. http://dx.doi.org/10.1162/GLEP a 00051

Ajzen, I., and M. Fishbein. 2005. The influence of attitudes on behavior. Pages 173-221 in D. Albarracín, B. T. Johnson, and M. P. Zanna, editors. The handbook of attitudes. Erlbaum, Mahwah, New Jersey, USA.

Anthony, K. R. N., J. A. Maynard, G. Diaz-Pulido, P. J. Mumby, P. A. Marshall, L. Cao, and O. Hoegh-Guldberg. 2011. Ocean acidification and warming will lower coral reef resilience. Global Change Biology 17(5):1798-1808. http://dx.doi.org/10.1111/ j.1365-2486.2010.02364.X

Armitage, C. J., and M. Conner. 2001. Efficacy of the theory of planned behaviour: a meta-analytic review. British Journal of Social Psychology 40:471-499. http://dx.doi.org/10.1348/014466601164939

Arnocky, S., and M. Stroink. 2010. Gender differences in environmentalism: the mediating role of emotional empathy. Current Research in Social Psychology 16(9):1-14. [online] URL: https://evolutionlab.nipissingu.ca/wp-content/uploads/sites/20/2014/10/ Arnocky-Stroink-2011b.pdf

Ballantine, B. 1995. Networks of "no-take" marine reserves are practical and necessary. Pages 13-20 in L. Shackell and J. H. Martin Willison, editors. Marine protected areas and sustainable fisheries. Science and Management of Protected Areas Association, Nova Scotia, Canada.

Beeden, R., J. Maynard, J. Johnson, J. Dryden, S. Kininmonth, and P. Marshall. 2014a. No-anchoring areas reduce coral damage in an effort to build resilience in Keppel Bay, southern Great Barrier Reef. Australasian Journal of Environmental Management 21(3):311-319. http://dx.doi.org/10.1080/14486563.2014.881307

Beeden, R. J., M. A. Turner, J. Dryden, F. Merida, K. Goudkamp, C. Malone, P. A. Marshall, A. Birtles, and J. A. Maynard. $2014 b$. Rapid survey protocol that provides dynamic information on reef condition to managers of the Great Barrier Reef. Environmental Monitoring and Assessment 186(12):8527-8540. http://dx.doi. org/10.1007/s10661-014-4022-0

Biggs, D. 2011. Understanding resilience in a vulnerable industry: the case of reef tourism in Australia. Ecology and Society 16(1):30. http://dx.doi.org/10.5751/ES-03948-160130

Biggs, D., N. C. Ban, and C. M. Hall. 2012. Lifestyle values, resilience, and nature-based tourism's contribution to conservation on Australia's Great Barrier Reef. Environmental Conservation 39(4):370-379. http://dx.doi.org/10.1017/ $\underline{\mathrm{S} 0376892912000239}$

Biggs, D., C. C. Hicks, J. E. Cinner, and C. M. Hall. 2015. Marine tourism in the face of global change: the resilience of enterprises to crises in Thailand and Australia. Ocean and Coastal Management 105:65-74. http://dx.doi.org/10.1016/j.

ocecoaman.2014.12.019

Bohensky, E., N. Marshall, M. Curnock, S. Gillet, J. Goldberg, M. Gooch, P. Pert, L. Scherl, S. Stone-Jovicich, and R. Tobin. 2014. The social and economic long-term monitoring program (SELTMP) 2013: coastal communities in the Great Barrier Reef. Report to the National Environmental Research Program. Reef and Rainforest Research Centre, Cairns, Australia. [online] URL: http://www.nerptropical.edu.au/sites/default/files/publications/files/ NERP-TE-PROJ-10.1-SELTMP-2013-COASTAL-COMMUNITIESComplete.pdf

Bryman, A. 2012. Social research methods. Oxford University Press, Oxford, England.

Buttel, F. H. 1979. Age and environmental concern: a multivariate analysis. Youth and Society 10(3):237-256. http://dx.doi. org/10.1177/0044118X7901000302

Clayton, S., P. Devine-Wright, P. C. Stern, L. Whitmarsh, A. Carrico, L. Steg, J. Swim, and M. Bonnes. 2015. Psychological research and global climate change. Nature Climate Change 5 (7):640-646. http://dx.doi.org/10.1038/nclimate2622

Clayton, S. D., and S. Opotow. 2003. Identity and the natural environment: the psychological significance of nature. MIT Press, Cambridge, Massachusetts, USA.

Connell, S., J. Fien, J. Lee, H. Sykes, and D. Yencken. 1999. 'If it doesn't directly affect you, you don't think about it': a qualitative 
study of young people's environmental attitudes in two Australian cities. Environmental Education Research 5(1):95-113. http://dx. doi.org/10.1080/1350462990050106

Curnock, M., N. Marshall, R. Tobin, S. Stone-Jovicich, E. Bohensky, P. Pert, J. Goldberg, M. Gooch, S. Gillet, and L. Scherl. 2014a. The social and economic long-term monitoring program (SELTMP) for the Great Barrier Reef 2013: tourism report to the National Environmental Research Program. CSIRO, Townsville, Australia. [online] URL: http://www.nerptropical.edu.au/sites/ default/files/publications/files/NERP-TE-PROJ-10.1-SELTMP-2013TOURISM-Complete.pdf

Curnock, M., N. Marshall, R. Tobin, S. Stone-Jovicich, E. Bohensky, P. Pert, J. Goldberg, M. Gooch, F. Heindler, J. Parker, S. Gillet, and L. Scherl. 2014b. The social and economic long-term monitoring program (SELTMP) 2014: tourism in the Great Barrier Reef. Report to the National Environmental Research Program. CSIRO, Cairns, Australia.

Day, J. C., and K. Dobbs. 2013. Effective governance of a large and complex cross-jurisdictional marine protected area: Australia's Great Barrier Reef. Marine Policy 41:14-24. http://dx. doi.org/10.1016/j.marpol.2012.12.020

De'ath, G., K. E. Fabricius, H. Sweatman, and M. Puotinen. 2012. The 27-year decline of coral cover on the Great Barrier Reef and its causes. Proceedings of the National Academy of Sciences 109 (44):17995-17999. http://dx.doi.org/10.1073/pnas.1208909109

Deloitte Access Economics. 2013. Economic contribution of the Great Barrier Reef. Great Barrier Reef Marine Park Authority, Townsville, Australia. [online] URL: https://www.environment. gov.au/system/files/resources/a3ef2e3f-37fc-4c6f-ab1b-3b54ffc3f449/ files/gbr-economic-contribution.pdf

Department of Environment and Conservation (DEC-NSW). 2006. Who cares about the environment in 2006? A survey of NSW people's environmental knowledge, attitudes and behaviours. DEC Social Research Series, Sydney, Australia.

Devine-Wright, P., and S. Clayton. 2010. Introduction to the special issue: place, identity and environmental behaviour. Journal of Environmental Psychology 30(3):267-270. http://dx.doi. org/10.1016/S0272-4944(10)00078-2

Devine-Wright, P., and Y. Howes. 2010. Disruption to place attachment and the protection of restorative environments: a wind energy case study. Journal of Environmental Psychology 30 (3):271-280. http://dx.doi.org/10.1016/j.jenvp.2010.01.008

Dobbs, K., J. Day, H. Skeat, J. Baldwin, F. Molloy, L. McCook, M. Johnson, B. Elliot, A. Skeat, K. Vohland, D. Wachenfeld, and R. Kenchington. 2011. Developing a long-term outlook for the Great Barrier Reef, Australia: a framework for adaptive management reporting underpinning an ecosystem-based management approach. Marine Policy 35(2):233-240. http://dx. doi.org/10.1016/j.marpol.2010.10.007

Evans, N. 2011. More than a sign on the fence? Teacher learning and the Reef Guardian Schools Program in Far North Queensland. VDM Verlag Dr. Müller, Saarbrücken, Germany.

Fernandes, L., J. Day, A. Lewis, S. Slegers, B. Kerrigan, D. Breen, D. Cameron, B. Jago, J. Hall, D. Lowe, J. Innes, J. Tanzer, V.
Chadwick, L. Thompson, K. Gorman, M. Simmons, B. Barnett, K. Sampson, G. De'ath, B. Mapstone, H. Marsh, H. Possingham, I. Ball, T. Ward, K. Dobbs, J. Aumend, D. Slater, and K. Stapleton. 2005. Establishing representative no-take areas in the Great Barrier Reef: large-scale implementation of theory on marine protected areas. Conservation Biology 19(6):1733-1744. http://dx. doi.org/10.1111/j.1523-1739.2005.00302.X

Fransson, N., and T. Gärling. 1999. Environmental concern: conceptual definitions, measurement methods, and research findings. Journal of Environmental Psychology 19(4):369-382. http://dx.doi.org/10.1006/jevp.1999.0141

Frieler, K., M. Meinshausen, A. Golly, M. Mengel, K. Lebek, S. D. Donner, and O. Hoegh-Guldberg. 2012. Limiting global warming to $2 \mathrm{C}$ is unlikely to save most coral reefs. Nature Climate Change 3(2):165-170. http://dx.doi.org/10.1038/nclimate1674

Fuj, E. T., M. Hennessy, and J. Mak. 1985. An evaluation of the validity and reliability of survey response data on household electricity conservation. Evaluation Review 9(1):93-104. http://dx. doi.org/10.1177/0193841X8500900106

Gelman, A. 2008. Scaling regression inputs by dividing by two standard deviations. Statistics in Medicine 27(15):2865-2873. http://dx.doi.org/10.1002/sim.3107

Gist, M. E., and T. R. Mitchell. 1992. Self-efficacy: a theoretical analysis of its determinants and malleability. Academy of Management Review 17(2):183-211.

Goldberg, J., N. Marshall, A. Birtles, P. Case, E. Bohensky, M. Curnock, M. Gooch, H. Parry-Husbands, P. Pert, R. Tobin, C. Villani, and B. Visperas. 2016. Climate change, the Great Barrier Reef and the response of Australians. Palgrave Communications 2:15046. http://dx.doi.org/10.1057/palcomms.2015.46

Grayson, M. 2013. Agriculture and drought. Nature 501(7468): S1-S1. http://dx.doi.org/10.1038/501S1a

Great Barrier Marine Park Authority. 2007. Great Barrier Reef climate change action plan 2007-2011. Great Barrier Reef Marine Park Authority, Townsville, Australia. [online] URL: http://www. gbrmpa.gov.au/managing-the-reef/threats-to-the-reef/climate-change/ climate-change-action-plan

Great Barrier Marine Park Authority. 2009. Great Barrier Reef outlook report 2009. Great Barrier Reef Marine Park Authority, Townsville, Australia. [online] URL: http://www.gbrmpa.gov.au/ managing-the-reef/great-barrier-reef-outlook-report/outlook-report-2009

Great Barrier Marine Park Authority. 2012. Great Barrier Reef climate change adaptation strategy and action plan (2012-2017). Great Barrier Reef Marine Park Authority, Townsville, Australia. [online] URL: http://elibrary.gbrmpa.gov.au/jspui/bitstream/11017/1140/1/ GBR $\% 20$ Climate $\% 20$ Change $\% 20$ Adaptation $\% 20$ Strategy $\% 20$ and $\%$ 20Action $\% 20$ Plan $\% 202012-2017$.pdf

Great Barrier Marine Park Authority. 2014. Great Barrier Reef outlook report 2014. Great Barrier Reef Marine Park Authority, Townsville, Australia. [online] URL: http://www.gbrmpa.gov.au/ managing-the-reef/great-barrier-reef-outlook-report

Griskevicius, V., R. B. Cialdini, and N. J. Goldstein. 2008. Social norms: an underestimated and underemployed lever for managing climate change. IJSC 3:5-13. [online] URL: http://citeseerx.ist. psu.edu/viewdoc/download?doi=10.1.1.433.5428\&rep=rep1\&type $=$ pdf 
Grothmann, T., and A. Patt. 2005. Adaptive capacity and human cognition: the process of individual adaptation to climate change. Global Environmental Change-Human and Policy Dimensions 15 (3):199-213. http://dx.doi.org/10.1016/j.gloenvcha.2005.01.002

Halpenny, E. A. 2010. Pro-environmental behaviours and park visitors The effect of place attachment. Journal of Environmental Psychology 30(4):409-421. http://dx.doi.org/10.1016/j.jenvp.2010.04.006

Hochschild, J., A. Crabill, and M. Sen. 2012. Technology optimism or pessimism: how trust in science shapes policy attitudes toward genomic science. Issue in Technology Innovation at Brookings 21. [online] URL: https://www.brookings.edu/wpcontent/uploads/2016/06/genomic-science.pdf

Honnold, J. A. 1984. Age and environmental concern - some specification of effects. Journal of Environmental Education 16 (1):4-9. http://dx.doi.org/10.1080/00958964.1984.9942695

Horton, P. B., and C. L. Hunt. 1984. Sociology. Sixth Edition. McGraw-Hill, New York, New York, USA.

Howard, G. S. 1997. Ecological psychology: creating a more earthfriendly human nature. University of Notre Dame Press, Notre Dame, Indiana, USA.

Hughes, T. P., N. A. J. Graham, J. B. C. Jackson, P. J. Mumby, and R. S. Steneck. 2010. Rising to the challenge of sustaining coral reef resilience. Trends in Ecology and Evolution 25(11):633-642. http://dx.doi.org/10.1016/j.tree.2010.07.011

Hughes, T. P., J. T. Kerry, M. Álvarez-Noriega, J. G. ÁlvarezRomero, K. D. Anderson, A. H. Baird, R. C. Babcock, M. Beger, D. R. Bellwood, R. Berkelmans, T. C. Bridge, I. R. Butler, M. Byrne, N. E. Cantin, S. Comeau, S. R. Connolly, G. S. Cumming, S. J. Dalton, G. Diaz-Pulido, C. M. Eakin, W. F. Figueira, J. P. Gilmour, H. B. Harrison, S. F. Heron, A. S. Hoey, J.-P. A. Hobbs, M. O. Hoogenboom, E. V. Kennedy, C.-Y. Kuo, J. M. Lough, R. J. Lowe, G. Liu, M. T. McCulloch, H. A. Malcolm, M. J. McWilliam, J. M. Pandolfi, R. J. Pears, M. S. Pratchett, V. Schoepf, T. Simpson, W. J. Skirving, B. Sommer, G. Torda, D. R. Wachenfeld, B. L. Willis, and S. K. Wilson. 2017. Global warming and recurrent mass bleaching of corals. Nature 543 (7645):373-377. http://dx.doi.org/10.1038/nature21707

Jenks, B., P. W. Vaughan, and P. J. Butler. 2010. The evolution of Rare Pride: using evaluation to drive adaptive management in a biodiversity conservation organization. Evaluation and Program Planning 33(2):186-190. http://dx.doi.org/10.1016/j.

evalprogplan.2009.07.010

Johnson, J. E., and P. A. Marshall. 2007. Climate change and the Great Barrier Reef: a vulnerability assessment. Great Barrier Marine Park Authority and Australian Greenhouse Office, Australia. [online] URL: http://www.gbrmpa.gov.au/managingthe-reef/threats-to-the-reef/climate-change/how-climate-change-canaffect-the-reef/great-barrier-reef-vulnerability-assessment

Kittinger, J. N., E. M. Finkbeiner, E. W. Glazier, and L. B. Crowder. 2012. Human dimensions of coral reef social-ecological systems. Ecology and Society 17(4):17. http://dx.doi.org/10.5751/ ES-05115-170417

Kollmuss, A., and J. Agyeman. 2002. Mind the gap: why do people act environmentally and what are the barriers to pro- environmental behavior? Environmental Education Research 8 (3):239-260. https://doi.org/10.1080/13504620220145401

Laurance, W. F., G. R. Clements, S. Sloan, C. S. O'Connell, N. D. Mueller, M. Goosem, O. Venter, D. P. Edwards, B. Phalan, A. Balmford, R. Van Der Ree, and I. B. Arrea. 2014. A global strategy for road building. Nature 513(7517):229-232. http://dx.doi. org/10.1038/nature13717

Lewis, S. E., J. E. Brodie, Z. T. Bainbridge, K. W. Rohde, A. M. Davis, B. L. Masters, M. Maughan, M. J. Devlin, J. F. Mueller, and B. Schaffelke. 2009. Herbicides: a new threat to the Great Barrier Reef. Environmental Pollution 157(8-9):2470-2484. http:// dx.doi.org/10.1016/j.envpol.2009.03.006

Lucas, P. H. C., T. Webb, P. S. Valentine, and H. Marsh. 1997. The outstanding universal value of the Great Barrier Reef World Heritage Area. Great Barrier Reef Marine Park Authority, Townsville, Australia. [online] URL: http://hdl.handle.net/11017/301

MacDonald, E., T. Milfont, and M. Gavin. 2015. Thinking globally but not acting locally?: Expert and public rerceptions of environmental threats and conservation actions. Human Dimensions of Wildlife 20(2):123-132. http://dx. doi. org/10.1080/10871209.2015.963748

Maibach, E. W., A. Leiserowitz, C. Roser-Renouf, and C. K. Mertz. 2011. Identifying like-minded audiences for global warming public engagement campaigns: an audience segmentation analysis and tool development. Plos One 6(3). http://dx.doi.org/10.1371/journal.pone.0017571

Malka, A., J. A. Krosnick, and G. Langer. 2009. The association of knowledge with concern about global warming: trusted information sources shape public thinking. Risk Analysis 29 (5):633-647. http://dx.doi.org/10.1111/j.1539-6924.2009.01220.x

Marshall, N. A. 2006. A conceptual and operational understanding of social resilience in a primary resource industry: insights for optimizing social and environmental outcomes in the management of Queensland's commercial fishing industry. Dissertation. James Cook University, Townsville, Australia. [online] URL: https:// researchonline.jcu.edu.au/1629/

Marshall, N. A. 2010. Understanding social resilience to climate variability in primary enterprises and industries. Global Environmental Change-Human and Policy Dimensions 20 (1):36-43. http://dx.doi.org/10.1016/j.gloenvcha.2009.10.003

Marshall, N., E. Bohensky, M. Curnock, J. Goldberg, M. Gooch, B. Nicotra, P. Pert, L. Scherl, S. Stone-Jovicich, and R. Tobin. 2016. Advances in monitoring the human dimension of natural resource systems: an example from the Great Barrier Reef. Environmental Research Letters 11(11):114020. http://dx.doi. org/10.1088/1748-9326/11/11/114020

Marshall, N., P. Marshall, and A. Abdulla. 2009. Using social resilience and resource dependency to increase the effectiveness of marine conservation initiatives in Salum, Egypt. Journal of Environmental Planning and Management 52(7):901-918. http:// dx.doi.org/10.1080/09640560903180982

Marshall, N. A., S. E. Park, W. N. Adger, K. Brown, and S. M. Howden. 2012. Transformational capacity and the influence of place and identity. Environmental Research Letters 7(3):034022. http://dx.doi.org/10.1088/1748-9326/7/3/034022 
McCook, L. J., T. Ayling, M. Cappo, J. H. Choat, R. D. Evans, D. M. De Freitas, M. Heupel, T. P. Hughes, G. P. Jones, B. Mapstone, H. Marsh, M. Mills, F. J. Molloy, C. R. Pitcher, R. L. Pressey, G. R. Russ, S. Sutton, H. Sweatman, R. Tobin, D. R. Wachenfeld, and D. H. Williamson. 2010. Adaptive management of the Great Barrier Reef: a globally significant demonstration of the benefits of networks of marine reserves. Proceedings of the National Academy of Sciences 107(43):18278-18285. http://dx. doi.org/10.1073/pnas.0909335107

McKinley, E., and S. Fletcher. 2010. Individual responsibility for the oceans? An evaluation of marine citizenship by UK marine practitioners. Ocean and Coastal Management 53(7):379-384. http://dx.doi.org/10.1016/j.ocecoaman.2010.04.012

Milliken, F. J. 1987. Three types of perceived uncertainty about the environment: state, effect, and response uncertainty. Academy of Management Review 12(1):133-143. http://dx.doi.org/10.2307/257999

Mobley, C., and W. Kilbourne. 2013. Gender differences in proenvironmental intentions: a cross-national perspective on the influence of self-enhancement values and views on technology. Sociological Inquiry 83(2):310-332. http://dx.doi.org/10.1111/ j.1475-682X.2012.00431.X

Moscardo, G. 2008. Exploring public awareness of threats to the Great Barrier Reef environment. Interdisciplinary Environmental Review 10(1/2):45-64. http://dx.doi.org/10.1504/IER.2008.053961

Moser, S. C. 2010. Communicating climate change: history, challenges, process and future directions. WIRESs-Climate Change 1(1):31-53. http://dx.doi.org/10.1002/wcc.11

Moser, S. C., and L. Dilling. 2004. Making climate hot communicating the urgency and challenge of global climate change. Environment 46(10):32-46. http://dx.doi. org/10.1080/00139150409605820

Moser, S. C., and J. A. Ekstrom. 2010. A framework to diagnose barriers to climate change adaptation. Proceedings of the National Academy of Sciences 107(51):22026-22031. http://dx.doi. org/10.1073/pnas.1007887107

Nisbet, E. K., J. M. Zelenski, and S. A. Murphy. 2009. The nature relatedness scale linking individuals' connection with nature to environmental concern and behavior. Environment and Behavior 41(5):715-740. http://dx.doi.org/10.1177/0013916508318748

Novacek, M. J. 2008. Engaging the public in biodiversity issues. Proceedings of the National Academy of Sciences 105:11571-11578. http://dx.doi.org/10.1073/pnas.0802599105

Nunnally, J. C. 1978. Psychometric theory. Second edition. McGraw-Hill, New York, New York, USA.

O'Neill, S., and S. Nicholson-Cole. 2009. "Fear won't do it" promoting positive engagement with climate change through visual and iconic representations. Science Communication 30 (3):355-379. http://dx.doi.org/10.1177/1075547008329201

Olsson, P., C. Folke, and T. Hahn. 2004. Social-ecological transformation for ecosystem management: the development of adaptive co-management of a wetland landscape in southern Sweden. Ecology and Society 9(4):2. http://dx.doi.org/10.5751/ ES-00683-090402
Partridge, E. 2008. From ambivalence to activism: young people's environmental views and actions. Youth Studies Australia 27(2).

Pauly, D., and D. Zeller. 2016. Catch reconstructions reveal that global marine fisheries catches are higher than reported and declining. Nature Commununications 7:10244. http://dx.doi. org/10.1038/ncomms 10244

Perry, R. I., M. Barange, and R. E. Ommer. 2010. Global changes in marine systems: Aasocial-ecological approach. Progress in Oceanography 87(1-4):331-337. http://dx.doi.org/10.1016/j. pocean.2010.09.010

Podsakoff, P. M., S. B. MacKenzie, J.-Y. Lee, and N. P. Podsakoff. 2003. Common method biases in behavioral research: a critical review of the literature and recommended remedies. Journal of Applied Psychology 88(5):879-903. http://dx.doi.org/10.1037/0021-9010.88.5.879

R Core Team. 2017. R: a language and environment for statistical computing. Version 3.3.2. The $\mathrm{R}$ Foundation for Statistical Computing, Vienna, Austria. [online] URL: https://www.rproject.org/

Rickard, L. N., Z. J. Yang, M. Seo, and T. M. Harrison. 2014. The "I" in climate: the role of individual responsibility in systematic processing of climate change information. Global Environmental Change-Human and Policy Dimensions 26:39-52. http://dx.doi.org/10.1016/j.gloenvcha.2014.03.010

Scannell, L., and R. Gifford. 2013. Personally relevant climate change: the role of place attachment and local versus global message framing in engagement. Environment and Behavior 45 (1):60-85. http://dx.doi.org/10.1177/0013916511421196

Schultz, P. W. 2000. Empathizing with nature: the effects of perspective taking on concern for environmental issues. Journal of Social Issues 56(3):391-406. http://dx.doi.org/10.1111/0022-4537.00174

Shove, E. 2010. Beyond the ABC: climate change policy and theories of social change. Environment and Planning $A 42$ (6):1273-1285. http://dx.doi.org/10.1068/a42282

Stedman, R. C. 2002. Toward a social psychology of place predicting behavior from place-based cognitions, attitude, and identity. Environment and Behavior 34(5):561-581. http://dx.doi. org/10.1177/0013916502034005001

Steg, L., and C. Vlek. 2009. Encouraging pro-environmental behaviour: an integrative review and research agenda. Journal of Environmental Psychology 29(3):309-317. http://dx.doi.org/10.1016/ j.jenvp.2008.10.004

Sundström, A., and A. M. McCright. 2013. Examining gender differences in environmental concern across four levels of the Swedish polity. QoG Working Paper Series 10. Quality of Government Institute, Goteborg, Sweden. [online] URL: https:// qog.pol.gu.se/digitalAssets/1454/1454279 201310 sundstr--m mocright. pdf

Tobin, R., E. Bohensky, M. Curnock, J. Goldberg, S. Gillet, M. Gooch, N. Marshall, B. Nicotra, P. Pert, L. Scherl, and S. StoneJovicich. 2014a. The social and economic long term monitoring program (SELTMP) 2013: commercial fishing in the Great Barrier Reef. Report to the National Environmental Research Program. Reef and Rainforest Research Centre Limited, Cairns, Australia. 
[online] URL: http://citeseerx.ist.psu.edu/viewdoc/download? $\underline{\text { doi }=10 \cdot 1 \cdot 1.866 .4681 \& \mathrm{rep}=\text { rep } 1 \& \text { type }=\mathrm{pdf}}$

Tobin, R., E. Bohensky, M. Curnock, J. Goldberg, S. Gillet, M. Gooch, N. Marshall, P. Pert, L. Scherl, and S. Stone-Jovicich. 2014b. The social and economic long term monitoring program (SELTMP) 2013: recreation in the Great Barrier Reef. Report to the National Environmental Research Program. Reef and Rainforest Research Centre Limited, Cairns, Australia. [online] URL: http://citeseerx.ist.psu.edu/viewdoc/download? $\underline{\text { doi }=10.1 .1 .866 .4681 \& \mathrm{rep}=\text { rep } 1 \& \text { type }=\mathrm{pdf}}$

van der Linden, S. 2015. Intrinsic motivation and proenvironmental behaviour. Nature Climate Change 5(7):612-613. http://dx.doi.org/10.1038/nclimate2669

van Riper, C. J., G. T. Kyle, S. G. Sutton, J. I. Yoon, and R. C. Tobin. 2013. Australian residents' attitudes toward proenvironmental behaviour and climate change impacts on the Great Barrier Reef. Journal of Environmental Planning and Management 56(4):494-511. http://dx.doi.org/10.1080/09640568$\underline{.2012 .688650}$

Vaske, J. J., and K. C. Kobrin. 2001. Place attachment and environmentally responsible behavior. Journal of Environmental Education 32(4):16-21. http://dx.doi.org/10.1080/00958960109598658

Vörösmarty, C. J., P. B. McIntyre, M. O. Gessner, D. Dudgeon, A. Prusevich, P. Green, S. Glidden, S. E. Bunn, C. A. Sullivan, C. R. Liermann, and P. M. Davies. 2010. Global threats to human water security and river biodiversity. Nature 467(7315):555-561. http://dx.doi.org/10.1038/nature09440

Warriner, G. K., G. H. G. McDougall, and J. D. Claxton. 1984. Any data or none at all? Living with inaccuracies in self-reports of residential energy consumption. Environment and Behavior 16 (4):503-526. http://dx.doi.org/10.1177/0013916584164005

Whitmarsh, L. 2008. Are flood victims more concerned about climate change than other people? The role of direct experience in risk perception and behavioural response. Journal of Risk Research 11(3):351-374. http://dx.doi.org/10.1080/13669870701552235

Wynveen, C. J., G. T. Kyle, and S. G. Sutton. 2010. Place meanings ascribed to marine settings: the case of the Great Barrier Reef Marine Park. Leisure Sciences 32(3):270-287. http://dx.doi. org/10.1080/01490401003712705

Wynveen, C. J., and S. G. Sutton. 2015. Engaging the public in climate change-related pro-environmental behaviors to protect coral reefs: the role of public trust in the management agency. Marine Policy 53:131-140. http://dx.doi.org/10.1016/j.marpol.2014.10.030

Young, J., and R. Mar. 2010. Community perceptions of climate change and the effects on the Great Barrier Reef. Colmar Brunton, Brisbane, Australia.

Young, J., and J. Temperton. 2008. Measuring community attitudes and awareness towards the Great Barrier Reef: 2007. Great Barrier Reef Marine Park Authority, Townsville, Australia. [online] URL: http://dspace-prod.gbrmpa.gov.au/jspui/bitstream/11017/421/1/ Measuring-community-attitudes-awareness-towards-GBR-2007. pdf
Zelezny, L. C., P.-P. Chua, and C. Aldrich. 2000. New ways of thinking about environmentalism: elaborating on gender differences in environmentalism. Journal of Social Issues 56 (3):443-457. http://dx.doi.org/10.1111/0022-4537.00177 